20 next instead of within twelve months from the date of the protocol. Upon the decision of the case, the JodrNaL will publish a leading article concerning it, and the text of the award will be printed in the SuPpLEMENT.

\title{
WILLIAM L. PENFIELD
}

The passing away of a member of the American Society of International Law so eminent, both for learning and for practical service, in the domain of international affairs, as was the late Judge Penfield, is an event that obviously deserves to be commemorated in the Society's records.

William L. Penfield was born in the State of Michigan on the 2nd of April, 1846. His parents, who were natives of New England, were of English extraction. During his boyhood, which was spent on a farm, he attended the neighboring public schools; but he early became desirous of larger opportunities, and, after he had taken a course at Adrian College, he was entered as a student at the University of Michigan. Here, besides pursuing the regular classical curriculum, he devoted himself to studies in modern languages; and in 1870 he was graduated with high honors. Immediately afterwards, he was invited to become an instructor in Latin and in German at Adrian College. Accepting this offer, he held the position for two years; and during this time, in pursuance of a resolution long cherished, he fitted himself for the practice of the law. He was admitted to the bar, at Adrian, in 1872. In the following year, as the result of causes somewhat personal and accidental, he removed to Auburn, in Indiana; and there he remained, marrying and making the place his home, till he was called to Washington.

Judge Penfield's advancement in his profession was steady and sure. He soon secured a large clientage in the State and the Federal Courts. He also discharged various public functions, official and unofficial, such as those of city attorney, member of the Republican State Committee, presidental elector and electoral messenger, and delegate (in 1892) to the National Republican Convention. In 1894 he was nominated by the Republicans as their candidate for judge of the thirty-fifth judicial circuit of Indiana, and he had the satisfaction of being elected by the largest majority ever given to a judicial candidate in that circuit. In a memorial lately spread upon the records of the court in which he presided, his brethren at the bar have borne testimony to his unfailing courtesy, his "unswerving correctness of attitude," his "studiousness, 
his industry, and his profound knowledge of the law," at the same time declaring that "as a lawyer he always measured up to every requirement of the profession, and as a judge was actuated by a deep sense of right and a devotion to impartial justice."

In the spring of 1897, Judge Penfield resigned his judicial position in Indiana in order to accept the post of Solicitor of the Department of State of the United States, to which he was appointed by President McKinley. He entered upon the discharge of his new duties at a moment when many delicate and important questions were pending; and he was destined within the next few years, as an officer of the Department of State, to bear his part in dealing with various important crises in international affairs. In a year there came the war with Spain; then followed the troubles in China; and still later the war between Japan and Russia broke out. Meanwhile, difficult situations had been created in the western hemisphere by the blockade of Venezuelan ports by certain European powers, and by chronic disturbances, resulting in the prostration of governmental authority, in Santo Domingo. It is needless to say that by reason of these events, the labors and responsibilities of Judge Penfield's office were greatly enhanced; nor will there be any doubt, on the part of those who are acquainted with the facts, that his own individual labors and responsibilities, which were by no means confined to the ordinary work of his office, were exceptionally increased as the result of the special confidence which his official superiors felt in his abilities and his personal character.

In no part of his work did Judge Penfield exhibit a more absorbing interest than in that which related to the settlement of international disputes by arbitration. His record is in reality distinguished by his achievements in this direction. While others talked of arbitration, he made it a reality; and he had the happiness to appear as counsel for the United States in the first case - that of the "Pious Fund" of the Californias - before the Permanent Court at The Hague. This was. however, only one of the many arbitral proceedings in which he acted as the representative of his Government. He appeared again before The Hague Tribunal in the Venezuelan Arbitration in 1903-4; and at other times and before other tribunals, he represented demands against Peru, Haiti, Nicaragua, Guatemala, Salvador and Mexico. The judgments which he obtained for the United States aggregated more than two million dollars; but to his mind, while the award of substantial damages attested the validity of the demand, the greatest satisfaction, no doubt, 
was produced by the reflection that the end had been attained by a fair and open trial, with every opportunity to the parties to be heard.

In July 1905 Judge Penfield was sent as a special commissioner to Brazil. On his return to the United States he resumed the discharge of his regular duties; but, in the following year, he decided to lay down the burdens of office and to engage in private practice. He opened an office in Washington, and was soon retained in important cases. He was also appointed professor of international law and of the foreign relations of the United States in the postgraduate law school of Georgetown University. He died in Washington, May 9, 1909, prematurely, in the full tide of professional success.

Judge Penfield was a man of admirable gifts. While not professing to proceed by the intuitions of genius, he possessed to an unusual extent the faculty of logical analysis, which, united with patience and industry, enabled him to master the subject in hand, and, when he had mastered it, to present it with clearness and force. He was also persuasive. Versed in literature, and practised in writing and in speaking, he knew how to convey his thoughts in appropriate language, and, while sturdy in the maintenance of his views, bore himself with a courtesy that was innate and never lacking in dignity. But, if there was one trait more than another by which he was distinguished, it was his overruling sense of justice, a sense in his case cultivated and enlightened by study and by experience but ever directed to the ascertainment of the truth. In devoting to this ideal, unobscured by unworthy or extraneous considerations, his well-trained faculties, he has left behind him an example worthy not only of commemoration but also of imitation.

\section{DEDICATION OF THE PAN-AMERICAN BUILDING}

On April 26, 1910, the future home of the International Bureau of the American Republics was formally dedicated at Washington in the presence of the President and Secretary of State of the United States, representatives of the twenty-one Latin-American Republics, and Messrs. Root and Carnegie, whose interest in and devotion to the cause of the closer union of America have resulted in this outward and visible memorial to western civilization and to Pan-American solidarity.

The idea of a closer union of the American Republics has long been a favorite one of the enlightened and progressive spirits of America, and it is peculiarly appropriate that it be given definite form and effest in 